\title{
Environmental Impact Assessment of Selected Oil Production Facilities in Parts of Niger Delta, Nigeria
}

\author{
Samuel Bamidele Olobaniyi ${ }^{1}$, Omoleomeo Olutoyin Omo-Irabor ${ }^{2 *}$ \\ ${ }^{1}$ Department of Geology, University of Lagos, Lagos, Nigeria \\ ${ }^{2}$ Department of Earth Sciences, College of Science, Federal University of Petroleum Resources, Effurun, Nigeria \\ Email: sbolobaniyi@yahoo.com, ,omoirabor.omoleomo@fupre.edu.ng
}

Received 1 January 2016; accepted 21 February 2016; published 24 February 2016

Copyright (C) 2016 by authors and Scientific Research Publishing Inc.

This work is licensed under the Creative Commons Attribution International License (CC BY). http://creativecommons.org/licenses/by/4.0/

c) (†) Open Access

\section{Abstract}

The impact of oil production activities on the chemistry of soil and groundwater was investigated around seven production facilities, ranging from flow stations to wellhead in the western Niger Delta area. The method involved systematic sampling of soil and groundwater within a one kilometre radius of such facilities. The samples obtained were analysed for $\mathrm{pH}, \mathrm{TOC}, \mathrm{TPH}, \mathrm{V}, \mathrm{Ni}$ and Fe by standard procedures. The results indicate a general conformity of groundwater physico-chemistry to international standards for chemical potability. However, the investigated soil samples reveal in some cases elevated values of TPH (mean: $26.07 \mathrm{mg} / \mathrm{kg}$ ) and $\mathrm{Ni}$ (mean: $8.89 \mathrm{mg} / \mathrm{kg}$ ) which suggest a negative impact on the soil in the vicinity of such oil production facilities. Although groundwater may show no apparent contamination, pollutants trapped in the soil are in potential transit to groundwater, and may eventually be dissolved and transported through the soil profile to the water table by recharging rainwater. The environmental and health conditions of host communities are thereby endangered.

\section{Keywords}

Impact Assessment, Production Facilities, Soil, Groundwater, Heavy Metals, TPH, Niger Delta

\section{Introduction}

Nigeria is a country with a long history of oil exploration and exploitation. It is Africa's largest oil producing nation and ranks sixth in the world. Currently, Nigeria operates over 600 oil fields and in the process of granting

\footnotetext{
Corresponding author.
}

How to cite this paper: Olobaniyi, S.B. and Omo-Irabor, O.O. (2016) Environmental Impact Assessment of Selected Oil Production Facilities in Parts of Niger Delta, Nigeria. Journal of Water Resource and Protection, 8, $237-242$. 
more prospecting licences. However, the most important challenge confronting this industry is its inability to operate without significant degradation to the environment through soil, water and air pollution. Between the years 1976 and 1996, a total of 2,369,470 barrels of crude oil was estimated to have spilled into the environment [1], causing significant negative impact on the ecosystem [2]-[4], and eventually reducing the quality of life of the people. This among other factors has fuelled persistent agitation within the region, for a greater share from the central government, of the proceeds from oil.

Apart from major oil spills that occur along the pipelines predominantly through vandalisation, the aging operational facilities, including well heads and flow stations, constitute another, although a more subtle source of environmental contamination. Consequently, very little of their influence on the environment has been reported within the region. This paper examines aspects of the physico-chemistry of soil and groundwater in the vicinity of seven (7) oil production facilities within the western Niger Delta area and assesses the possible impact of such facilities on their environment.

\section{Study Area}

The seven studied facilities are all located in the following villages: Uzere, Igbide, Koko, Ologbo, Ozoro, Sapele and Afiesere, all within the western Niger Delta area (Figure 1). The setting is generally rural, while agriculture is the main occupation of the dwellers. The vegetation type varies from mangrove swamp to rainforest although prolonged human interference has modified in places this natural environment, and is now being replaced by grassland and shrubs.

The area is underlain by Cretaceous to Recent sedimentary sequences that constitute the Niger Delta. These sedimentary formations consist of fluviatile, marine and paralic sequences that are the sources and reservoir of hydrocarbon in the district. The topmost of these formations, usually the Coastal Plain Sands consists predominantly of continental loose sands and gravel with occasional clay intercalations [5].

\section{Methodology}

Five topsoil and groundwater (well water) samples each were collected systematically within a $1 \mathrm{~km}$ radius of 7 oil production facilities and the control site (Abraka). Three of these facilities were flow stations while 4 were

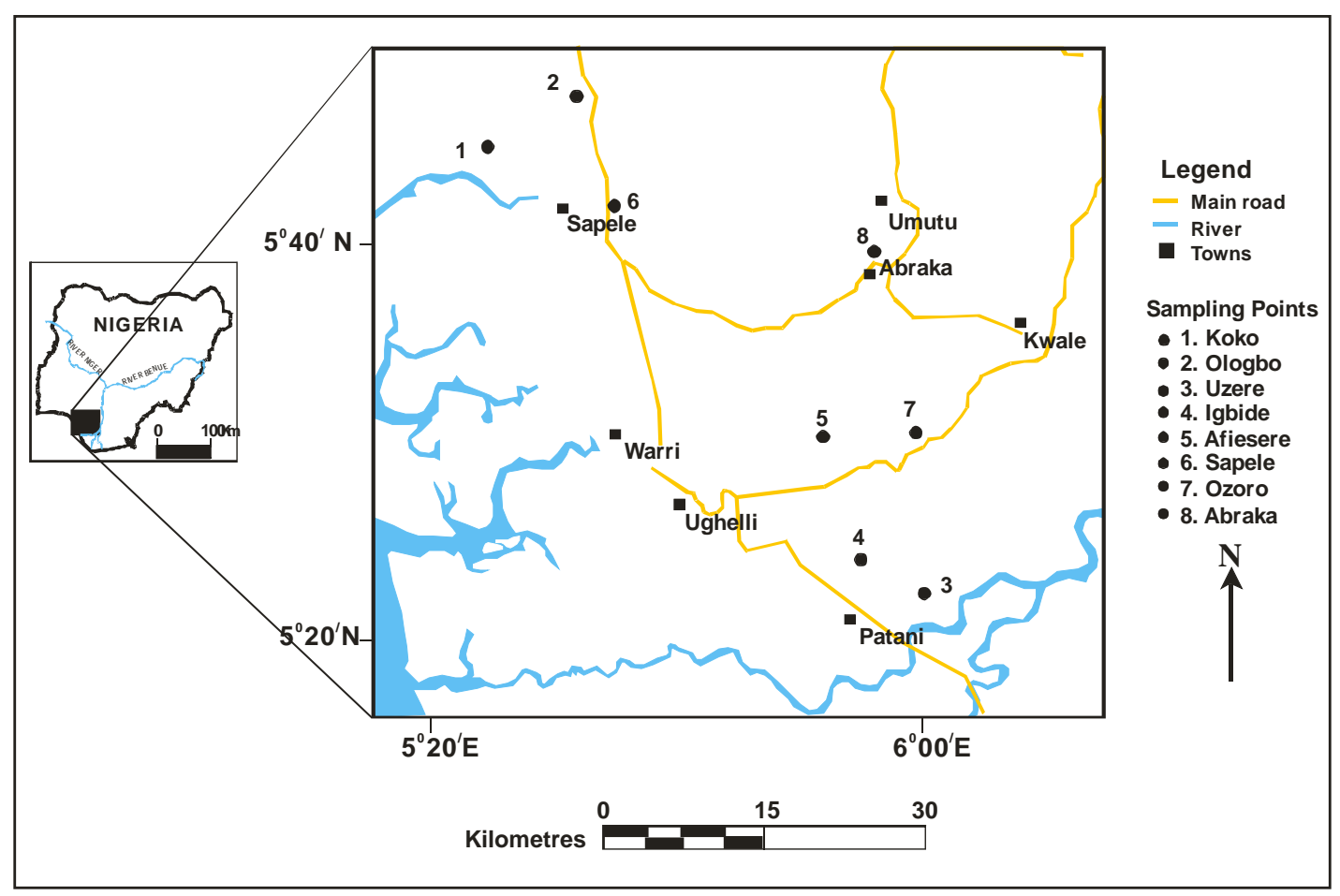

Figure 1. Map of part of Western Niger Delta showing study sites. 
production wellheads. One kg soil sample was collected from each sampling point and stored in plastic bags. Replicate water samples were collected into 1 litre plastic cans, one of which was acidified with $\mathrm{HNO}_{3}$ for heavy metal analysis. The samples were then stored in ice packed coolers to reduce changes in composition before analysis. Unstable parameters including temperature, dissolved oxygen (DO) and $\mathrm{pH}$ were measured in-situ using mercury-in-glass Celsius thermometer, Winkler's azide method and portable Orion Model $290 \mathrm{pH}$ meter respectively. For the samples, total organic carbon (TOC) was determined using the chromic acid titrimetric method. Total petroleum hydrocarbon (TPH) was measured with the gas chromatograph flame ionized detector (GCFID). $10 \mathrm{~g}$ of soil sample and $250 \mathrm{ml}$ homogenised water sample were extracted with dichloromethane. Sodium sulphate and silica were further applied for the removal of impurities and reduced in volume before analysis. Heavy metals (Ni, V, and Fe) were determined using flame atomic absorption spectroscopy (FAAS) technique at wavelengths of $232 \mathrm{~nm}, 318.4 \mathrm{~nm} \& 224.33 \mathrm{~nm}$ respectively. The soil analysis were carried out in the laboratory following standard procedures [6].

\section{Results}

The mean values of the physico-chemical data generated for soil and groundwater from each facility is presented graphically and compared with that from a non-impacted area (Figure 2 and Figure 3), whereas the statistical summary of all the mean values is presented in Table 1 and Table 2.

Soil samples show near neutral pH (6.30 - 7.37), generally low TOC (2.33 - $5.98 \mathrm{mg} / \mathrm{kg})$ and a highly variable TPH ( 4.51 - $76.68 \mathrm{mg} / \mathrm{kg}$ ) reflected in high standard deviation $( \pm 30.93) . \mathrm{V}(<0.001 \mathrm{mg} / \mathrm{kg})$ occurs below detection limit. However, Ni is slightly enhanced (5.34 - $9.10 \mathrm{mg} / \mathrm{kg}$ ) compared to the control site. Fe (7009 - $9725 \mathrm{mg} / \mathrm{kg})$

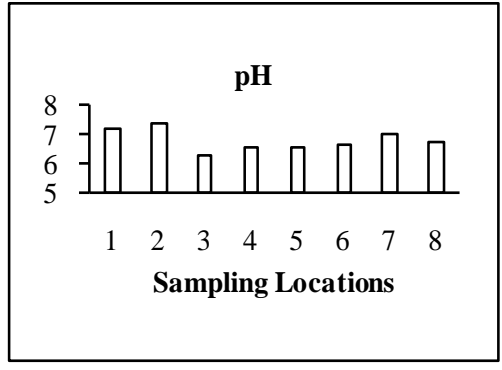

(a)

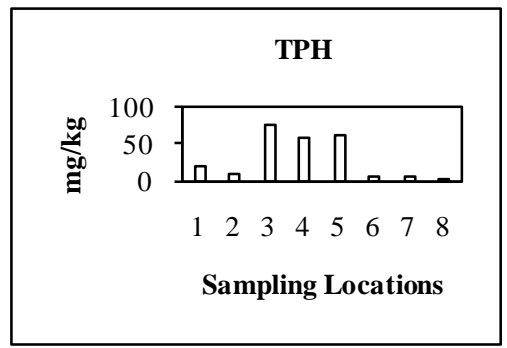

(c)

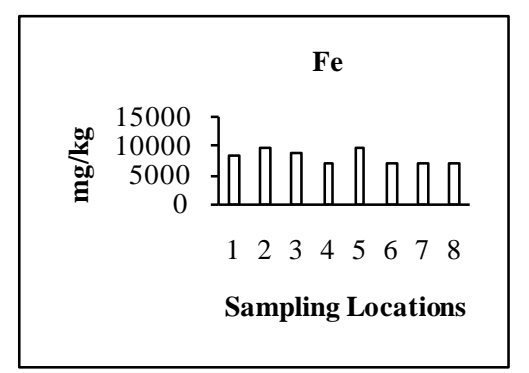

(e)

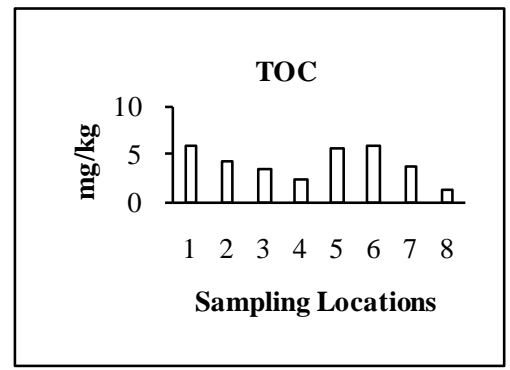

(b)

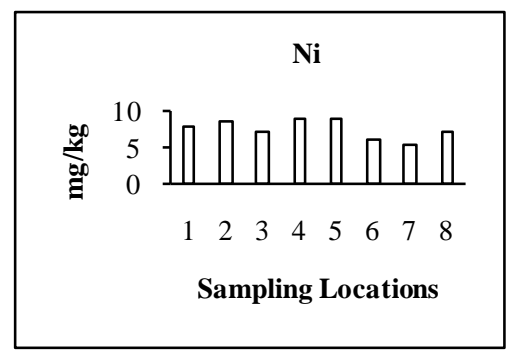

(d)
Locations

1. Koko

2. Ologbo

3. Uzere

4. Igbide

5. Afiesere

6. Sapele

7. Ozoro

8. Control site 


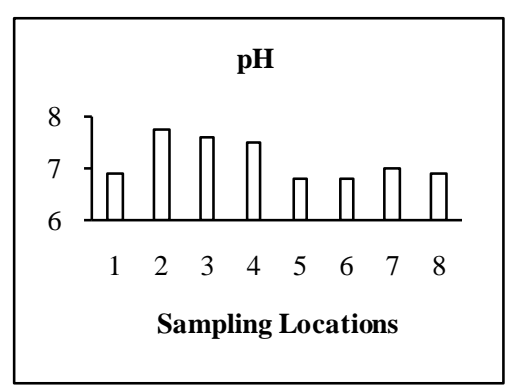

(a)

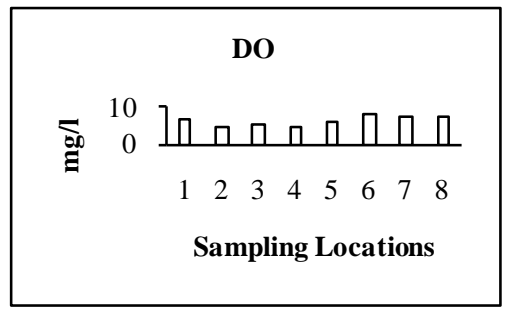

(c)

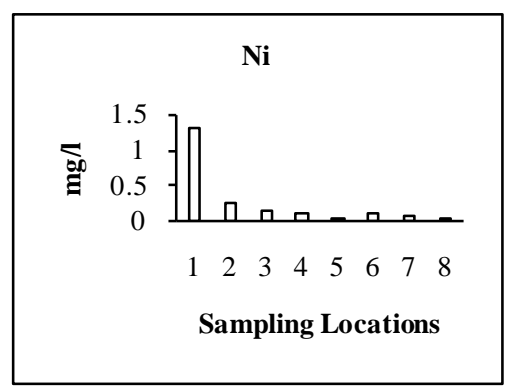

(e)

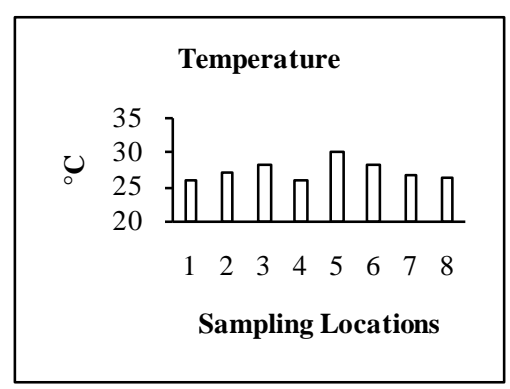

(b)

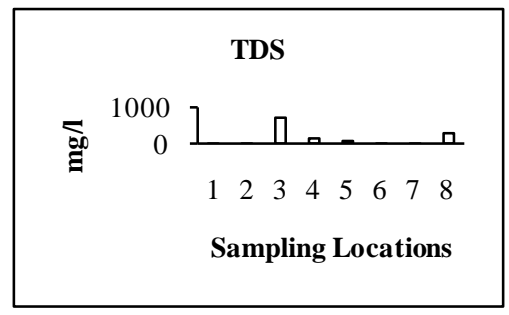

(d)

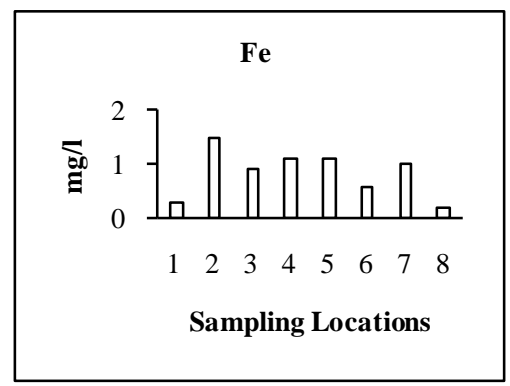

(f)

Figure 3. Average values of selected physico-chemical parameters in groundwater samples for the study locations.

Table 1. Statistical summary of investigated physico-chemical parameters in soils around the production facilities.

\begin{tabular}{ccccc}
\hline $\mathrm{n}=35$ & Minimum & Maximum & Mean & Std. deviation \\
\hline $\mathrm{Ph}$ & 6.30 & 7.37 & 6.83 & \pm 0.39 \\
$\mathrm{TOC} \mathrm{mg} / \mathrm{kg}$ & 2.33 & 5.98 & 4.59 & \pm 1.57 \\
$\mathrm{TPH} \mathrm{mg} / \mathrm{kg}$ & 4.51 & 76.68 & 26.07 & \pm 30.95 \\
$\mathrm{~V} \mathrm{mg/kg}$ & $<0.001$ & $<0.001$ & - & - \\
$\mathrm{Ni} \mathrm{mg/kg}$ & 5.34 & 9.10 & 8.89 & \pm 1.33 \\
$\mathrm{Fe} \mathrm{mg/kg}$ & 7009 & 9725 & 7667 & \pm 2234 \\
\hline
\end{tabular}

Table 2. Statistical summary of investigated physico-chemical parameters in groundwater around the production facilities.

\begin{tabular}{|c|c|c|c|c|}
\hline $\mathrm{n}=35$ & Minimum & Maximum & Mean & Std. deviation \\
\hline $\mathrm{pH}$ & 6.67 & 7.76 & 7.18 & \pm 0.47 \\
\hline Temp ${ }^{\circ} \mathrm{C}$ & 26.2 & 30.2 & 27.57 & \pm 1.55 \\
\hline DO mg/l & 4.99 & 7.63 & 6.33 & \pm 1.36 \\
\hline TDS mg/l & 35. & 35.6 & 168.37 & \pm 282.68 \\
\hline $\mathrm{V} \mathrm{mg} / \mathrm{l}$ & $<0.001$ & $<0.001$ & - & - \\
\hline Ni mg/l & 0.02 & 1.34 & 0.24 & \pm 0.53 \\
\hline $\mathrm{Fe} \mathrm{mg} / \mathrm{l}$ & 0.28 & 1.48 & 0.96 & \pm 0.46 \\
\hline
\end{tabular}


shows massively enhanced values in both study locations and control site, apparently reflecting the ferruginous nature of the soil.

The water samples show $\mathrm{pH}(6.78$ - 7.76) within the neutral range while DO values $(4.99-7.63 \mathrm{mg} / \mathrm{l})$ are moderate. TDS (35.6 - $752 \mathrm{mg} / \mathrm{l}$ ) varies widely indicating varied levels of solute content in the water samples. V $(<0.001 \mathrm{mg} / \mathrm{l})$ and $\mathrm{Fe}(0.28-1.48 \mathrm{mg} / \mathrm{l})$ are low. Ni occurs in generally moderate amounts (Figure 2) except around locations 1 and 2 where it exceeds the specification [7] (0.07 mg/l) for drinking water.

\section{Discussion}

The result of this study indicates that elevated TPH values ( $>50 \mathrm{mg} / \mathrm{kg}$ ) occurred in soils around $45 \%$ of the facilities investigated. This is in excess of $20 \mathrm{mg} / \mathrm{kg}$ specified safe limit for oil and grease in soils in the region [8]. Although the concentration of TPH was not determined in groundwater, the normal range of DO values recorded in the water samples imply that they have not been contaminated by hydrocarbon. This maybe as a result of the filtering and sealing effects of the interstratified clays within the Deltaic Plain Sands and Benin Formation that underlie the area [9]. Such filtering capability of the soil probably produced the slight accumulation of $\mathrm{Ni}$ in the soil samples. Within the Niger Delta region, high hydrocarbon content in soils has been implicated in low soil fertility [2] and plant toxicity [10] [11] and by implication low agricultural yield. Elsewhere, high cancer incidence has been linked to environmental contamination by hydrocarbons [12] and heavy metals [13]. With time, the trapped hydrocarbon, if not degraded, will get transported to the water table thereby endangering the health of the host communities.

\section{Conclusion}

Soil and groundwater samples were analysed to determine the extent of contamination within a one kilometre radius of seven oil production facilities in comparison with a control site. Elevated levels of total petroleum hydrocarbon (TPH) with mean values of $26.07 \pm 30.95 \mathrm{mg} / \mathrm{kg}$ were measured for soil around the facilities investigated while groundwater indicated low contamination of hydrocarbon from measured DO value. The occurrence of high concentrations of TPH in soils could lead to death of plants as a result of oxygen deficiency. Nickel is slightly enhanced in comparison with the control site while iron has a massively greater value in the eight sites as a result of the ferruginous nature of the soils in the study area. Vanadium was below detection limit for both soil and groundwater.

\section{References}

[1] Nwilo, P.C. and Badejo, O.T. (2006) Impacts and Management of oil Spill Pollution along the Nigerian Coastal Areas. Administering Marine Spaces: International Issues. A Publication of FIG Commission 4 \& 7 Working Group 4.3.

[2] Osuji, L.C. and Nwoye, I. (2007) An Appraisal of the Impact of Petroleum Hydrocarbons on Soil Fertility: The Owaza Experience. African Journal of Agricultural Research, 2, 318-324.

[3] Kadafa, A.A. (2012) Oil Exploration and Spillage in the Niger Delta of Nigeria. Civil and Environmental Research, 2, 38-51.

[4] Ite, A.E., Ibok, U.J., Ite, M.U. and Petters, S.W. (2013) Petrol Exploration and Production: Past and Present Environmental Issues in the Nigeria's Niger Delta. American Journal of Environmental Protection, 1, 78-90. http://dx.doi.org/10.12691/env-1-4-2

[5] Olobaniyi, S.B., Ogban, F.E., Ejechi, B.O. and Ugbe, F. (2005) Assessment of Groundwater Quality Variation across Delta State: Effects of Man, Geology and Hydrocarbon Exploitation. Unpublished Report, Delta State University, Cleveland.

[6] ASTM (2001) American Standard for Testing and Materials. New York.

[7] World Health Organization (2006) Guideline for Drinking Water Quality, Incorporating First Addendum: Volume 1. Recommendations. 3rd Edition, Geneva.

[8] DPR (1991) Environmental Guidelines and Standards for the Petroleum Industry in Nigeria. Department of Petroleum Resources, Ministry of Petroleum and Mineral Resources, Lagos.

[9] Owoyemi, F.B. and Olobaniyi, S.B. (2003) Investigation of Possible Groundwater Contamination in the Vicinity of Two Refuse Dumps in Warri, Niger Delta. Environmental Health in the Niger Delta, Centre for Environmental and Community Development, Warri, 33-39. 
[10] Baker, J.M. (1976) Marine Ecology and Oil Pollution. Applied Science Publishers Ltd., Essex.

[11] Amadi, A., Dickson, A. and Maate, G.O. (1993) Remediation of Oil Polluted Soils: 1. Effect of Organic and Inorganic Nutrient Supplements on the Performance of Maize (Zea may L.). Water, Air, and Soil Pollution, 66, 50-76. http://dx.doi.org/10.1007/BF00477060

[12] Hurtig, A. and Sebastian, M.S. (2002) Geographical Differences in Cancer Incidence in the Amazon Basin of Ecuador in Relation to Residence near Oil Fields. International Journal of Epidemiology, 31, 1021-1027. http://dx.doi.org/10.1093/ije/31.5.1021

[13] Olawoyin, R., Oyewole, S.A. and Grayson, R.L. (2012) Potential Risk Effect from Elevated Levels of Soil Heavy Metals on Human Health in the Niger Delta. Ecotoxicology and Environmental Safety, 85, 120-130. http://dx.doi.org/10.1016/j.ecoenv.2012.08.004 